\title{
THE COMMUNICATION TOOLS OF TURKEY'S ARAB TRIBES WITH OTHER ETHNIC GROUPS: MARRIAGE, RELIGION AND MUSIC
}

\section{Deniz AȘKIN ${ }^{1}$}

\section{ABSTRACT}

This study analyzes the Turkish Arabs's security concepts, intra-tribal marriage, cultural dimension of religion and their interactions with the other groups they live together through the example of Shego and Bidri tribes. The Arab tribes of Shego and Bidri remained in the area surrounded by mountains for a very long time and stayed away from the reform policies of the central government and the interaction with the rest of the world. Therefore, the ethnocultural identities of these tribes, which were recognized as a result of their rebellions that started with centralization and continued with the Republican administration process, exhibit an endemic characteristic and are influenced by the societies in which they live with. In these tribes, the local Arabic language, daily life, their relations with the religion and state are shaped as a result of their identity codes. This study reveals the ethnocultural identities and interactions of Shego and Bidri tribes, which are recorded just in the late Ottoman period and continue with the Republic of Turkey, on an anthropological and sociological basis.

Keywords: Turkey Arabs, Tribal Ideology, Tribal Identity, Ethno-Cultural Identities, Islamization of Anatolia 


\section{TÜRKIYYE'DEKİ ARAP AŞİRETLERİNIN DİĞER ETNİK GRUPLARLA İLETİŞIM KANALLARI: EVLILIIK, DİN VE MÜZİK}

\section{ÖZ}

Bu çalışma Şego ve Bıdri aşiretleri örneğinde Türkiye'deki Arapların güvenlik anlayışlarını, aşiret içi evliliklerini ve kültürel kimliğin dinsel boyutları ile beraber yaşadıkları diğer etno-kültürel kimliklerle etkileşimlerini sosyolojik bir zeminde incelemektedir. Şego ve Bıdri Arap aşiretleri dağlar ile çevrili alanda kalarak merkezi yönetimin ıslahat politikalarından ve dış dünya ile etkileşimden uzak kalmışlardır. Bu nedenle merkezileşme ile başlayan ve cumhuriyet yönetimi süreci ile devam eden isyanlar neticesinde haberdar olunan bu aşiretlerin günümüzdeki etno-kültürel kimlikleri endemik bir özellik sergilemekle beraber yaşadıkları toplumlardan da etkilenmektedirler. Söz konusu aşiretlerde Yerel Arapça, gündelik hayat, din ve devlet ile kurdukları ilişkiler sahip oldukları kimlik kodları neticesinde şekillenmektedir. Bu çalışma Osmanlı son dönemi ile kayıtlara geçen ve cumhuriyet ile devam eden söz konusu endemik Şego ve Bıdri aşiretlerinin etno-kültürel kimliklerini ve etkileşimlerini antropolojik ve sosyolojik bir zeminde ortaya koymaktadır.

Anahtar Kelimeler: Türkiye Arapları, Aşiret İdeolojisi, Aşiret Kimliği Etno-Kültürel Kimlikler, Anadolu'nun Müslümanlaşması. 


\section{INTRODUCTION}

This study focuses on the ethnocultural identity of the two Arab tribes (Shego and Bidri), which were astonishingly reflected in the reports (Safi Pasha, 1890; Taylor, 1865; Sykes, 1908 ) prepared during the Ottoman period as being detached from the outside world and influenced by the Armenian culture. However, what makes this work important is that these tribes, which have been culturally closed and geographically limited to a region for nearly 1000 years, are not subject to an academic study until recently redundant in the Ottoman period and in the Republic of Turkey. The histories of these tribes, which Safi Pasha (1890) discovered during the Ottoman centralization policy and the preparation of reform programs for the tribes in this context, also contain important data in terms of reflecting the Armenian-Arab-Kurdish-Turkish ethnic interaction (Aşkın, 2020a; 2020b). The mountainous and reassuring nature of the Sason region ${ }^{2}$, which was in the border of Bitlis province during the Ottoman period, allowed and encouraged Armenians to live with the tribes there (Hovanissian, 2016: 9). However, this region was not a safe area only for non-Muslims but also for Muslim tribes who wanted to act independently and tried to maintain their own area dominance. Considering the Shego and Bidri tribes, it is seen that their identity has been protected/preserved with the help geography of and different forms of culture. The phrase Kanunsuz Sason (Lawless Sason) is used even today for the Sason region among the local population, possibly because it is a region of detached tribes. As each tribe tried to implement its own rule and opposed tax and centralization (Karadeniz, 2011: 34), the successive rebellions in the region began to take place in the transition to the Republic government.

In this study tribes are understood as a socio-politic system based upon ancestor that are real or thought to be real and blood related relationship (Bruinessen, 2013: 82). They have been created in traditional societies in the historical process, provide a collective culture and identification pathway for individuals before the transition to modern society, providing political, social and economic needs. As Karasu

${ }^{2}$ Today it remains within the boundaries of Batman province of Turkey.

SAD / JSR

Cilt / Volume 24 Sayı / Number 2 
(2018: 61) states that the structure makes necessary for tribe members to be together for better and worse (tasada ve kıvançta). The tribal structure, which we can trace significantly even today, has lost some characteristics, but it still has a significant impact on the rural areas of the Eastern and Southeastern Anatolia regions of Turkey (Karadeniz, 2011: 30; Uluç, 2010: 37). A tribal organization, which is built on the basis of similarities (Bruinessen, 2013: 82; Yalçın-Heckmann, 2012) is also related to the process and scope of the spread of geography and modernization parameters to the region. This situation, which can be expressed as both cause and effect, allows tribal systems and culture to change more slowly. Beşikçi (1992: 101) states that it is important to come together and be together so that the organizational structure can continue its existence. Otherwise, cultural differences mixed into a fragmented and dominant culture may soon be integrated into the upper identity. Considering the particular Arab tribes, although they are far away from the Zaza and Kurds tribes around the mountainous areas of the region, the confidence provided by their organization and social, political and economic solidarity within themselves has caused these tribes to develop limited relations with other neighboring tribes. Apart from the short-term unrest come up with the Republic (Sason rebellions between 1925-1937), these Arab tribes have developed a close relationship with the governments of State. The cultural and political positions in these relations, which are manifested in social life among the Kurdish-Arab tribes and developed based on competition, show that the Arabs in Turkey and the state have developed rational strategic relations.

The aim of this study is not to depict the history and populated geography of the shego and bidri tribes but to provide a different perspective on the ethnocultural identity of them. Since there is not any academic researches on these tribes in English, it is quite necessary to mention this issue briefly. As mentioned earlier, these tribes were not recorded in detail until the late Ottoman period (Aşkın, 2020a; 2020b). The report of Sykes (1908) shows that these tribes are among the groups sent by the Abbasid caliph to Islamize Anatolia which was under the control of the Armenians at that time. The report also mentions that these tribes (Musi, Sarmi, Zakari), led by Sheikh Nasrettin, killed King Tavit and made the region Muslim (Aşkın, 2020b: 266). In addition to those quoted by Sykes (1908) and Safi Pasha 
(1890), M. Zeki Beg (2015) combined the information of Bitlis Salnamesi (1890) and Taylor (1865), making possible to reach a strong claim about the settlement and historical information of these tribes. According to the mentioned sources these Arab tribes, who came to Islamize Anatolia under the leadership of Sheikh Nasrettin sent by the Abbasid caliph from the region of Iraq, settled in the region of Sason by demolishing the rule of King Tavit. In addition, the Armenians who stayed in the region lived together under their control (Aşkın, 2019; 2020a; 2020b). Later, these tribes, which cut off the contacts with the outside world and grew up in the region they inhabited, were particularly influenced by Armenians who they lived together and had an older materialistic and written culture than the Arabs in the Sason region (Safi Pasha, 1890; Taylor, 1865). The claim that these tribes remained within the borders of the Sason region (also spreading to Kozluk and Garzan region) until the 1850s is a strong assertion when considering the oral history applied through the members of this tribe (Aşkın, 2019: 485; 2020b; 267) and the Bitlis Salname's data and Sykes' study. The members of these tribes shown in the Bitlis Provincial Yearbook (Bitlis Salname) (1892) within the boundaries of Mutki claim that they also spread through villages vacated by the Armenian relocation. Looking at the geography of the settlement of the tribes, it is seen that these places are largely connected by mountain roads.

\section{METHOD}

Ethnographic studies, which are among anthropological and sociological research area of social sciences, are carried out to reach comprehensive information about the general or specific aspect of society (Denzin and Lincoln, 2005: 3, Saukko, 2005: 344). As a qualitative method ethnography makes for researchers to collect data related to social and cultural specialties of small groups with the way of observation, interview and participation, and then interpret them (Naidoo, 2012). An ethnographic perspective also provides a very important method for this study. The daily lives of the Shego and Bidri tribes, their relations with the neighboring tribes, the use of local language, the cultural dimension of religion, the way the members present themselves, the ways of communication developed with the state and institutions provide the emergence of more important data for an ethnographic perspective (Aşkın, 2020a: 165). The ethnocultural identity codes and sociological features of these tribes, which can be 
depicted with an ethnographic study, and the documents and data based on oral history are presented within the scope of this study both by observation and by interview. This study aims at obtaining general data about the Shego and Bidri tribes and gives importance to their interpretation of related issues within their own cultural structures. In this context, with an interpretive perspective, we focus on the question of 'how' for the construction of meaning by paying attention to the practice of creating meaning with its own values because each culture should be interpreted in its own particular way (Naidoo, 2012: 2; Neuman, 2012: 131). The observation and interviews with the group members and the relationships between the individuals and the social life establish a meaningful unity with their own perspective. This study is based on the data collected on the basis of an ethnographic method and interpretive understanding of social science, as well as, the participant observation and the records of interviews with tribal members between November of 2019 and January of 2020. During the fieldwork process, the framework of the research was prepared by visiting these Arab tribe villages in Bitlis province and examining the everyday lives, cultural structures, language and religious practices used by the tribal members with the observation method. Later, 20 questions were prepared using the observation data, and in-depth interviews were conducted with the tribe members within the scope of the semi-structured interview form. In this study, which used a random sampling method, a total of 23 tribe members ${ }^{3}$ residing in Bitlis province and accepting to participate in the study were interviewed for 1-3 hours.

These tribes, which inhabited in their geographical region by building their own cultural relations and loyalty, are not a group that was later integrated into the socio-cultural structure of the region. On the contrary, they constitute one of the oldest societies in the region. Hence the structure of the modern period that triggered the emergence of minority identities (Parekh, 2006; 1) cannot be applied to these groups. Again, unlike the groups of the modern period that have created their own distinguish identity, as a general framework, these tribes are on the way of articulation to the upper identity rather than a

${ }^{3}$ During the fieldwork, 23 tribe members were interviewed, and the men were coded as $\mathrm{M}$ and the women as $\mathrm{W}$. 
struggle for existence in the socio-political system of the country. In this way, the ethnocultural identity used in this study is not political, but rather social and cultural. Ethno-cultural identity approach and the use of language that forms its own values system (Karasu, 2018: 62; Özer, 2000: 11) under the upper identity (üst kimlik), which does not belong to any other culture, point to the type of culture that forms in the region within the ethnic structure with an exclusive identity. Ethno-cultural identity provides an efficient space for discussing and identifying behavior codes and identity components of a group (Yamada and et al., 1988: 36), it is also an important source of reference in determining the traditional and widespread trend of group. The change that occurs during a cultural interaction or integration process manifests itself in the everyday lives of group members through clothing, conversation, relationship or behavior change, and gender roles. The failure of these tribes to have any written tradition or concrete institutional structure has also accelerated their interactions and affection. As a matter of fact, it is possible to examine behavioral changes, linguistic influences, self-presentation situations, and identity codes through the ethnocultural identity approach with the dimension of belief by using the group (tribe) member status of individuals.

\section{SECURITY AND THE ACCEPTANCE OF ETHNO-CULTURAL IDENTITY OF THE SHEGO AND BIDRI TRIBES}

The relationship between governments and safety is significantly influential in the political positioning of the Shego and Bidri tribes. As the ruling party gains the power to represent the state itself, it is seen that it gains legitimacy among tribe members as well. The active members of the tribes in politics $(\mathrm{M}$, $2 ; M, 5)$ clearly state their political positions with the statement of "our side is evident", and when asked to elaborate this sentence, it is clearly understood that this is a discourse in favors of the ruling party. One tribe member said that "Shego and Bidri tribes have always felt the need to establish good relations with the State because of a perception of terrorism towards the Kurds and it is independent of party. Whichever party is in power, our tribe shows their loyalty to State” (M, 10), so his remarkable statement $(\mathrm{M}, 10)$ reflects the fact that they are a minority in the region and have the need to articulate to a higher identity. 
As another tribe member puts it, "tribe members lack a national consciousness", and more importantly, their understanding reflects the tribal-based organization and power and social relations and determines their interaction with the outside world. In the same way, a tribal member said, "Our people feel the need to connect to a higher identity, namely Turkish identity against the dangers that may come from the Kurds in recent years. Between us, however, the state is understood in the modern sense by a concept of government rather than a concept of State. In other words, the idea of 'State is God' prevails between $u s ”(\mathrm{M}, 6)$, which shows that security is nurtured from a tribal-based perception and that a movement towards the tribe causes clustering among themselves, which results from a minority-based situation. Likewise, it is understood that tribal members have preferred to accept another authority to avoid regional dangers. This point is also emphasized by Karasu (2018: 66) about tribes located in Şanliufra, Turkey. In an interview with a member of the Bidri tribe who is active in politics, his statement that "the state should not leave us alone in the region, we have always been on the side of our state" (M.22) confirms the information. More clearly, the recognition of the state together with its authority is also an important reason for the idea of protection against regional dangers, but such clusters are based on volunteering rather than an obligation (Kressel, 2003: 863). Another tribal member explains the relationship of the tribe with the state as follows; "what our people want to do is to articulate themselves to a higher identity and to get rid of local dangers, what our people do is an oriental cunning” (M, 8); This statement confirms the idea that the state is perceived as a security tool. These thoughts, where tribal identity is protected, show that a minority group wants to merge with the stronger one to prevent themselves from local dangers.

This relationship affects the convergence of tribal organization to the state mechanism (Bruinessen, 2019: 9), which severely affects social, cultural, political, and economic relations, whereas the importance of common consumption products (economics, religion, language, power, etc.) in forming unity is undeniable (Jacobsen, 1995: 83). Also, people who establish the means of connection between tribal members and the state are as important as this relationship. Such persons, who stand out directly with the absence of a leader, make themselves accepted both in the state channels and other members of 
the tribe through their behavior. In this way, the minority group builds a linkage mechanism between the upper identity and themselves. At this point, Ferzende Doğan is an important example even recorded in the state's secret reports (Aşiretler Raporu, 2014: 90). When asked Ferzende Doğan's position within the tribe to the tribal members, it can be understood that he is a very honest, very brave, strong and influential person, but not a traditional leader, he has built his own charismatic personality in the process. As an example of the statements of tribal members that he is a person who has good relations with government institutions and whose words are listened to, this statement is important; "When they were said to become official rangers for the region, the Shego tribal was hesitant, but he (Ferzende Doğan) said that everyone would take a gun, and the whole tribe accepted the offer." (M, 4). This confirms the expectation that the most important task for a tribal chieftain/leader is to build a bridge between his own tribe and other tribes and the state (Bruinessen, 2019: 14). In this context, the leading people of tribe build their own legitimacy in the outside world by means of the bridge they create in most cases for proving themselves.

\section{MARRIAGE AND REPRODUCTION OF TRIBAL IDEOLOGY}

The modern approach used in understanding and interpreting the Eastern and Southeastern Anatolia regions of Turkey leads to considering tribal-based organizations as an extension of tradition and defining basic cultural values as archaic. But solidarity and organized structure in such societies, although not legal, are more effective, giving confidence to group members by maintaining their collective identity codes. Indeed, to solve the problems together and the situation of unification around the ortak akl (common mind) to overcome the problem requires rethinking the dominant set of values used by such structures as the form of social interpretation in Turkey. Similarly, as Ökten (2009: 100) emphasizes, the evaluation of the family structure in the region from a modernizing perspective can lead to an incomplete analysis. In these societies, where the traditional structure is measured by the number of households, the parameters such as culture, old age, labor power, and familial ties remain unimportant. 
Malinowski (1989: 138) points to the shared emotional integrity of people who gather around the same group, highlighting that the reason for people to form a partnership together is the reaction of people for the same situation. In other words, in response to the past experiences of individuals, the members act together in many situations, such as mourning, excitement, religious ceremony, which causes them to gather around the same group and affects the formation of the sense of belonging by exhibiting ethnocultural characteristics. In such congregational structures, where individual identity is dimmed under common collective identity, emotional situations are more prominent today. The Arab tribes in question display different characteristics from the minority and dominant culture in the region, causing their ethnic and cultural characteristics to be kept more alive than the other dominant cultural elements. Indeed, it is possible to state that these Arab tribes have displayed a slightly more closed society for marriage.

The observations and interviews reveal that exogamy is not an accepted case, especially in those residing in rural areas. It is understood that such a tendency is generally conducted by tribal organizations as shown by Uluç and Karasu (2015: 218). However, the reasons behind marriages can be changeable. Among this reasons language difference is the leading factor. In addition, cultural and ethnic prejudices, familial, individual/intellectual differences suggest that they reduce this situation to a limited level, at least by preventing exogamy. One tribal member said, “Among us, the Kurds' familial relations are not appreciated, and both the perception of terror and the idea that they are rude prevent us from marrying them" (M, 1). Despite such considerations, there may be marriages with Kurdish tribal members, especially in the case where the reference is strong. "In the past, much attention was paid, but nowadays, everyone knows Kurdish, so they don't pay much attention" said one tribal member during a meeting in the Güroymak region, indicating that the obstacle was minimized by learning the language. It is necessary to emphasize the determinism of language in this direction. An interviewer who identified her mother as being of Kurdish origin said that "People still mock my mother's Arabic in our house" (W, 1), which is also important in terms of showing the state of influence between cultures. 
In such groups, where the difference in ethnic-belonging is supported by cultural phenomena such as language, the interaction with external groups has a limited opportunity to take place. In the negotiations, exogamy was reflected as never acceptable for some tribal members. For example, a person reveals this by saying, "My father did not approve of my marriage and did not do my wedding because I was marrying a woman from the outside" (M, 9). In this respect, it is the result that marriage from outside or from within the tribe is an issue that needs to be dealt with more on a family basis. That is why the decision of marriage is made as a result of the perception shaped according to the contact, interaction, and communication of the head of the family with the outside world.

This social reality, which points to the fact that marrying the daughter of uncle is the right of the cousin first, continues to influence the Shego and Bidri tribes as well. In this respect, if a person is to marry someone from outside the tribe, first of all, the approval of the children of uncle must be obtained. At this point, the statement "if the girl is beautiful, the children of her uncle will not allow her to marry a man from the outside, they think it is their right, this thought is still continuing between us" $(\mathrm{M}, 7)$ affirms this situation. Bruinessen (2019: 23) states that this 'parallel cousin marriage', which occurs among tribal members, actually harbors a tribal ideology. In a more open statement, he states that it is a strategy taken to protect the common ancestor against the danger of fragmentation and division of the tribe. This situation, in which the sense of "us and others" is felt, is based on the way tribal members perceive the outside world categorically. This sociological reality, which occurs as a result of marriage with a close relative, is also caused by the perception of individuals as their responsibilities over each other and the idea of maintaining their own characteristics of tribal/kinship relations. In this aspect, the leading people in the tribe, or older ones, emphasize that they expect young people to act more consciously in this issue (Altunek, 2001: 23; Jacobson, 1995: 86).

There are also a number of functions of tribes or smaller organizations in this form of marriage. Considering the tribes of Shego and Bidri, marriage is also seen as an important factor in maintaining the linguistic structure. Because a possible mixture/interaction that may occur due to the local nature of 
the language will lay the groundwork for the loss of the culture that is inherent through the language (Aşkın, 2020a: 166). However, it is not possible to limit this to just language. The idea of a common ancestor, devotion to the ancestral land, the preservation of tribal tradition can also be endangered by exogamy. However, the perception that this kind of marriage with cousin increases the ability of families to intervene in the possible divorce or marital conflict is often expressed by tribal members who are interviewed. Therefore, family elders consider this situation as a responsibility.

\section{MUSIC AS AN INTERACTION CHANNEL FOR THE TRIBES WITH OTHERS}

It is observed that the direction of the interaction of the Arab tribes Shego and Bidri is shaped by the ethnocultural identity with which they live together. It is reflected in historical reports that during the Ottoman period these tribes were influenced by Armenians who had settled in the region before them and had concrete culture (Safi Pasha, 1890; Sykes, 1908; Taylor, 1865). Safi Pasha (1890) indicates that this interaction is both in everyday life and religious belief. The important aspect of the report, which may be an object of historical sociology, is that these tribes were severely influenced by Armenians both in social life and in faith. At this point, especially the expression of "they call their children with Armenian name to live much longer" (Safi Pasha, 1890) is important in terms of this study because of its resemblance to the situation of being influenced by Kurdish tribes (Aşkın, 2020a; 159; Aşkın, 2020b: 266). The deportation of Armenians from the region or the distribution of tribal members to different geographies, as quoted above, provided the basis for their influence from other tribal members with whom they were close.

The fact that the research population is tribal members in Bitlis makes it possible and necessary to give examples in this study for their influence on Kurdish ethnocultural identity. The Kurdish language skills, religious practices and social life, and agricultural activities of tribal members, which are remarkable in everyday life, also indicate their influence. Considering the similar names, this situation becomes clear in terms of comparison and interaction, as in the example of Armenians. Today, Arab tribal members living especially in Güroymak and Mutki districts give their own children Kurdish names, which can be 
expressed as an important channel of interaction. The most common names in the fieldwork are Dilan, Berfin, Rojda, Diyar, Zozan, Berivan, Şehriban, which are frequently used in the region and imply connotations of Kurdish ethnic belonging. It was seen in the observations and interviews that common consumption cultures in social life were important in the realization of the interaction.

The economic affairs realized together with neighboring tribes or indigenous people, also the dominant cultures as Kurdish and Turkish have caused local Arabic to be influenced by these two languages. Music, especially, greatly accelerates the development and process of a common culture (Simonett, 2007; O'flynn, 2007). Similarly, with Kurdish music listened predominantly in the village vans and other personal repertoires, it should be noted that a common cultural pot in the regional base has developed in favor of Kurdish but against the local Arabic language. The reason for this was asked to a young and educated tribal member, and he stated that "I was influenced by my Kurdish friends and the surrounding Kurdish culture” (W, 1), which is important for this study. While this statement points to the prevailing culture, it also shows that the cultural and belonging relations and identity codes of Shego and Bidri tribes have entered the process of change. Similarly, an interviewed tribal member stated that "We listen to Kurdish music at home, even if we cannot translate it" (W, 2), which shows that although tribal members understand the lyrics of music, they do not have sufficient Kurdish language skills for the translation and pronunciation. It is also possible to see that brings a sense of regret. One of the tribal members said that "Imagine how sad that we are having a wedding but it is happening entirely according to the Kurdish traditions and customs. We wish let's sing a folk song but there is no our music” (M, 12). The thoughts that refer to this kind of identity loss are mostly seen among educated people, however, tribal members living in the countryside emphasize that this is a natural process. But it is noteworthy that music builds a channel of cultural interaction. In other words, this culture of entertainment seriously determines the names that people give to their own children.

When asked a person whose child's name was Zozan, he said that he was very impressed by the Kurdish artist Zozan, and a tribal member whose brother's name was Berivan said that his father liked the Kurdish 
artist Berivan, showing the same results. While it is not possible to distinguish music from historicalsocial culture and it is severely affected by current events, it also affects the listener group. In particular, the musicians make a variety of evocations in mind, so personality appreciation or physical admiration increases their influence rate. In this way, the influence of music on cultural change and interaction in the tribal members of Shego and Bidri is extremely important. As a result of the relationship they have established with society, politics, religion, and culture (Göher, 2009), music has the power to influence and determine consumer orientation and perception. For this reason, tribal members show a tendency in this direction and make an attempt to honor the artists "whom they feel to be an interpreter of their feelings" (Özel, 2016:162).

Although we do not have enough data, it can be stated that the tribal members listened to Armenian music during the Ottoman period, when they were far from the Kurdish tribes. Because if there was a musical culture, it would be possible for the members to bring it into the future. Even the absence of musical culture in the Sason region, which is the ancient settlement centers of the present-day Shego and Bidri tribes, supports this argument. As a result, tribal members have been severely affected by the communities they have lived with after coming from Baghdad to the Sason region until today, and these have been assimilated with their ethnocultural identity codes.

Almost all of the interviewed women and men do not watch the TRT Arabic channel because they do not understand, which shows the degrees of differentiation from modern Arabic. Instead, older people prefer to watch the TRT Kurdi and mention that they understand this channel language better, revealing important data. That is why the Arabic used by tribal members is quite different from the other Arab states, as well as different from Arabic used in some cities in Turkey, such as Mardin, Hatay, and Sanliurfa. A tribal member says that "we do not understand TRT Arabic in any way, so we do not follow, TRT Kurdi is more important and valid for us", which is important in terms of validation of the above data. When asked about this, a tribe member said that "we have been living with the Kurds for many years, so our situation of being affected by the Kurds is quite high. Also, there is absolutely no national 
consciousness in our Arabs, our people use Arabic as a means of communication only" (M, 13); This statement contains important data. While it is expected that national awareness will be formed with TRT Arabic, the lack of importance among the tribal members of this channel, in a way, significantly reduces its influence. Given that the transfer of language to the next generation is also not generally considered, it is possible to argue that the change of means of communication will also neutralize the state of building a national consciousness (Aşkın, 2020b: 270).

\section{DETERMINANTS OF RELIGION AND FAITH IN THE TRIBES OF SHEGO AND BIDRI}

All members of Bidri and Shego tribes are Muslim Sunni-Shafi, which is consistent with the dominant religious and sectarian category in the region. However, considering the report notes prepared by Safi Pasha (1890), it is understood that the Armenians later fortified their religious beliefs as well as their daily lives. The report clearly states that mosques and schools should be built in the region and that religious officials should be appointed. The efforts to move the concrete cultural structures of Islam to the region and to enable the tribes to remember and obey their own Islamic identity with the help of governor Arif Pasha can be seen in the records of Ottomans (Safi Pasha, 1890). It is possible to think in line with current developments that the re-islamization of these tribes took shape through the dominant religious codes in the region. Today, the influence of religion on the formation and organization of society is not seen in the Shego and Bidri tribes; However, in daily life and especially in the individual dimension, the guiding influence of religion is clear. Religious references in oaths used in everyday speeches are quite frequent. Especially among men and women in the countryside, attention is also paid to sit separately. But one of the main characteristics which distinguishes the tribes of Shego and Bidri ethnically and culturally from neighboring tribes is that they do not have a culturally religious leader. Historically, local religious leaders such as the Sheikh and Seydas, who rose to prominence in the region after commanders, have been effective in guiding the community (Aşkın, 2018: 179). In other words, as an active factor of the upper class among the Kurds, the counterpart of the sheiks or seydas does not appear among the Arab tribes in the region. This situation has eliminated a class of ulama and a culture 
of prominence by religious reputation among themselves. Therefore, the absence of the traditional madrasa education, which is widely present in Eastern and Southeastern Anatolia, among the tribal members suggests that they do not have an institutional-traditional religious education. When asked whether they had religious leaders, their statement "We are tied to the Kurdish sheiks in this respect" $(\mathrm{M}, 1)$ opens a new channel for them to be influenced by the sociological structure of the neighboring tribes. Furthermore, the fact that some of the tribal members often swear by the name of the Kurdish Sheik closest spatially to them in their daily speeches shows the extent of their interaction. However, it also reveals that local groups have selective channels of interaction (Olwig, 1993:364). In other words, they have built a channel of interaction in the religious sense in addition to their own Arab identity and culture. To give an example, the tribal members of the Mutki region want to increase their credibility by swearing on the name" Kavakbaşı Sheikh Mullah Zübeyir" who is close to them. In this direction, the expression "on the name of Mullah Zübeyir", which is common in the Mutki Arabs, aims to increase the persuasive power of the word during the speech. In addition, it is often emphasized by the tribal members that the Shego and Bidri tribal members in Güroymak region feel closer to the Norşin (Güroymak) Sheikh (Nurettin Mutlu) emotionally with the sense of belonging. 


\section{CONCLUSION}

One of the most important parameters of today's tribal organizations to actively claim collective identity is the result of the relationship they have established with the state in the historical process. The effect of the tribal organization, which continued to maintain easier administration and necessary regional sensitivities in the Ottoman Empire, on determining political candidates in the elections of today's Turkey is indisputable. At this point, the tribal relationships of the candidates in the eastern and southeastern regions of Turkey appear to be a strong reference. In this respect, it appears that the state and tribal systems have close contact in the region, which feeds each other and makes each other strong, while this relationship has recently progressed in the tribal-politics dilemma. In brief, it is observed that these structures, which are forbidden legally, have been entered into the political scene. With a lack of national consciousness, the Arab tribes have pursued a policy of closeness to the state to protect themselves from regional and local dangers, that is why they have become involved in the paramilitary protection system. The ethnocultural dimension of these tribes, in which any party of power gains importance regardless of who is in power, is important in terms of bringing the security problem forward. The preservation of former culture in the Shego and Bidri tribes takes place in the context of an ethnocultural belonging rather than a national idea of consciousness. However, when looking at the general framework, it is possible to state that tribal members were affected by the dominant neighboring culture, especially with the Republican period. Indeed, this line is clearly exhibited in the political views of the tribal members, which express that the loyalty to the state through the current ruling party is evident in the determination of the changing cultural direction. The transfer of local language to the next generation further declines as they differentiate from rural culture. Local Arabic, where basic communication is provided in the rural area, is reduced in importance in individuals who diverge from the regional identity of the tribe, and the use of the language is determined through prominent individuals. However, the acquisition of music culture, especially from Kurdish, has caused them to interact with this language. This seems to be effective in naming tribal members' own children. It is noteworthy, however, that the taking of the names previously used by the Armenian community was a 
reference for the religion-belief, while the interaction developed with the Kurds especially with their music. Religion in the Arab tribes in question is an important object of analysis. These tribes, who lived with the Armenians for many years, did not have any written or concrete culture, which prepared the ground for their influence from the Armenians. However, the Ottoman reform programs and the Sason rebellion, the migrations from the ancient regions to the east and west of Turkey, and the Armenian relocation have enabled them to regain their Islamic identity which had previously been reduced to just a verbal level. 


\section{ÖZET}

Merkezileşme politikalarının Osmanlı Devleti'nin yönetiminde etkili olmaya başlaması ile yönetim programlarında çeşitli değişliklere gidildi. Bu durum devlet gücünü, sınır boyları ama özellikle o zamana kadar aşiret örgütlenmesi ile devam ettirilmiş ilişkilerin yoğun olduğu Türkiye'nin Doğu ve Güneydoğu Anadolu bölgelerinde önemli sosyolojik değişikliklere zemin hazırladı. Bölgedeki aşiretler için "devletin var ama uzakta olduğu düşüncesi” onların bu güç ile muhatap olma durumlarına da yansımıştır. Söz konusu bölgelerde cumhuriyet dönemine geçiş ile birlikte vuku bulan isyanlar sonucunda tahkim edilen devlet otoritesi yeni bir ilişkiler ağına zemin hazırlamıştır. Ulusal bir bilinçten yoksun olarak çoğunlukla Batman (Sason), Bitlis (Mutki, Güroymak, Tatvan) ve Muş (Merkez, Hasköy) sınırları içinde yaşayan Şego ve Bıdri Arap aşiretleri bölgesel ve yerel tehlikelerden korunmak için devlete yakınlık noktasında bir politika izledikleri ve bunun için de paramiliter koruculuk sistemine dâhil oldukları görülmektedir. İktidarın kim olduğundan ziyade iktidardan taraf olmanın önem kazandığı bu aşiretlerin etno-kültürel boyutu güvenlik problemini öne çıkarması açısından önemlidir. Şego ve Bıdri aşiretlerinde geçmiş kültürün korunması ulusal bir bilinç düşüncesinden ziyade etno-kültürel bir aidiyet bağlamında gerçekleşmektedir. Ancak genel çerçeveye bakıldığında, her iki aşiret üyelerinin özellikle Cumhuriyet dönemi ile beraber hâkim komşu kültürden etkilenme durumlarının olduğunu ifade etmek mümkündür.

Yerel dilin gelecek kuşağa aktarımı kırsal kültürden uzaklaştıkça daha da gerilemektedir. Kırsal alanda temel iletişimin sağlandığı lokal Arapça, aşiretin mekânsal kimliğinden uzaklaşan bireylerde önemi azalmakta ve dilin kullanım alanı seçili bireyler üzerinden belirlenmektedir. Bununla beraber Araplarda müzik tüketiminin özellikle Kürtçe üzerinden alınması onların bu dil ile etkileşime girmelerine neden olmuştur. Bunun ise aşiret üyelerinin kendi çocuklarına isim vermede etkili olduğu görülmektedir. Ancak daha önceleri verilen isimlerin Ermeni toplumundan alınmasının dini-inanç noktasında bir referansı olurken Kürtler ile özellikle müzik tüketimi ile geliştiği dikkat çekicidir. Söz konusu Arap aşiretlerinde din önemli bir analiz nesnesidir. Ermeniler ile uzun yıllar yaşayan bu aşiretler herhangi bir yazılı ya da somut kültüre sahip olmadıklarından süreç içerisinde Ermenilerden etkilenmelerine zemin 
hazırlamıştır. Ancak gerek Osmanlı ıslahat programları ve Sason isyanı sonrası gerekse de kadim bölgeden Türkiye'nin doğusuna ve batısına doğru gerçekleşen göç ve Ermeni tehciri onların sözlü düzeye indirgenen İslami kimliklerini de tekrardan edinmelerini sağlamıştır. 


\section{REFERENCES}

Altuntek, N. S. (2001). Türkiye Üzerinde Yapılmış Evlilik ve Akrabalık Araştırmalarının Bir Değerlendirmesi. Hacettepe Üniversitesi Edebiyat Fakültesi Dergisi, 18(2): 17-28.

Aşiretler Raporu (2014). 3. Basım. İstanbul: Kaynak Yayınları.

Aşkın, D. (2018). Din, Gelenek ve Modernleşme: Türkiye'de Şark Medreseleri ve Seydalar. Ankara: Nobel Yayınları.

Aşkın, D. (2019). Raporlar Ekseninde Bitlis Arapları: Tarihsel Sosyolojinin Harmanında Şego ve Bıdri Aşiretleri. M. Inbaşı And M. Demirtaş (Ed.), in Tarihi ve Kültürel Yönleri ile Bitlis (481-488). (Cilt 2). Bitlis: Bitlis Eren Üniversitesi Yayınları.

Aşkın, D. (2020a). Kentin Öteki Yüzleri: Bitlis’te Şego ve Bıdri Arap Aşiretleri Özelinde Kent, Kamusal Alan ve Dilin Sonraki Kuşağa Aktarımı. Deniz Aşkın (Ed.), in Bitlis: Kent, Kültür ve Toplum (s. 149-174). İstanbul: Pınar Yayınları.

Aşkın, D. (2020b). Etno-Kültürel Bir Kimlik Olarak Türkiye Arapları: Şego ve Bıdri Aşiretleri Örneğinde Tarih, Aşiret ve Devlet İlişkileri. Hacettepe Üniversitesi Edebiyat Fakültesi Dergisi, 37 (2), 263-275 . DOI: 10.32600/huefd.620559.

Beşikçi, İ. (1992). Doğu'da Değişim ve Yapısal Sorunlar (Göçebe Alikan Aşireti). Ankara: Yurt Yayınlar1.

Bitlis

$$
\text { Provincial Yearbook }
$$

1310 ,

M. 1892),

Http://Isamveri.Org/Salname/Sayilar.Php?Sidno=D02826

Bruinessen, M. V. (2013). A $\breve{g} a$, Şeyh ve Devlet. B. Yalkut (Trans.). İstanbul: İletişim Yayınları.

Bruinessen, M. V. (2019). Kürt Aşiretleri, Etnik Kimlik ve Orta Doğu'da Devlet. In Türkiye'de Aşiret Tartışmaları (p. 9-26). Ankara: Bağlam Yayınları.

Denzin N. K. and Lincoln, Y. S. (2005). Introduction: The Discipline and Practice of Qualitative Research. N. K. Denzin and Y. S Lincoln (Ed.), in The Sage Handbook of Qualitative Research (p. 1-32). USA: Sage Publications.

Göher, F. M. (2009). Müziğin Toplumsal İşlevi: Müzik, Siyaset, Din ve Ekonomi. In Müzik Kültürü ve Eğitimi. (Vol. 2) (p. 301-314). Ankara: Fayton Tanıtım Yayınları. 
Hovannisian, R. G. (2016). Ermeni Pağeş/Bitlis ve Daron/Muş. R. G. Hovannisian (Ed.), Z. Kılıç (Trans.) in Tarihi Kentler ve Ermeniler: Bitlis ve Muş (p. 7-44). İstanbul: Aras Yayınları.

Jacobsen, M. (1995). National Cultures and Local Identities: Cultural Persistency in the Face of Papua New Guinean National Encompassment. Ethnos: Journal of Anthropology, 60:1-2, 81-98, Doi: 10.1080/00141844.1995.9981509.

Karadeniz, S. (2011). Osmanlıdan Cumhuriyete Merkezileşme Politikalarının Aşiret Sistemine Etkileri Üzerine Kısa Bir Değerlendirme. Mukaddime, 3(3), 27-41. Retrieved from: https://dergipark.org.tr/tr/pub/mukaddime/issue/19674/210100

Karasu, M. A. (2018). Yerel Siyaset ve Yerel Siyasal Dinamikler Üzerinde Aşiret Etkisi (Şanlıurfa Örneği). A. Mengi and D. İşçioğlu (Ed.), in Küreselleşme Sürecinde Yerel Hizmet Yerel Siyaset (p. 55-78). Ankara: Ankara Üniversitesi SBF Yayınları.

Kressel, G. (2003). The Transformation of Nomadic Society in the Arab East. American Anthropologist, (105). 863-864. Doi:10.1525/Aa.2003.105.4.876.

Malinowski, B. (1989). İlkel Toplumlarda Cinsellik ve Baskı. H. Portakal (Trans.). İstanbul: Kabalc1 Yayınlar1.

Naidoo, L. (2012). Ethnography: An Introduction to Definition and Method. An Ethnography of Global Landscapes and Corridors, p. 1-9. https://doi.org/10.5772/39248.

Neuman, L. W. (2012). Toplumsal Araştırma Yöntemleri: Nitel ve Nicel Yaklaşımlar (Vol. 1). S. Özge (Trans.). İstanbul: Yayın Odası Yayınları.

O’Flynn, J. (2007). National Identity and Music in Transition: Issues of Authenticity in a Global Setting. I. Biddle and V. Knights (Ed.), in Music, National Identity and the Politics of Location (p. 1938). Hampshire: Ashgate Publishing.

Olwig, K. F. (1993). Defining the National in the Transnational: Cultural Identity in the Afro-Caribbean Diaspora. Ethnos, 58:3-4, 361-376, Doi: 10.1080/00141844.1993.9981482.

Ökten, Ş. (2009). Aşiret, Akrabalık ve Sosyal Dayanışma: Geleneksel Hayatı Yönetme Biçimi. Aile ve Toplum, 11 (5). 99-110.

Özel, C. (2016). 1980’lerden Günümüze İslamcı Müziğin Sosyolojik Analizi. Ankara Üniversitesi İlahiyat Fakültesi Dergisi, 57(1): 145-174. 
Özer, A. (2000). Doğu Anadolu'da Aşiret Düzeni. İstanbul: Boyut Yayınları.

Parekh, B. (2006). Rethinking Multiculturalism: Cultural Diversity and Political Theory. New York: Palgrave Macmillan.

Safi Paşa, M. S. (1890). BOA. Y.Prk.Um. 19/64, 01 R 1308.

Saukko, P. (2005). Methodologies for Cultural Studies: An Integrative Approach. N. K. Denzin and Y. S Lincoln (Ed.), in The Sage Handbook of Qualitative Research (p. 343-356). USA: Sage Publications.

Simonett, H. (2007). Banda, A New Sound from The Barrios of Los Angeles: Transmigrationand Transcultural Production. I. Biddle and V. Knights (Ed.), in Music, National Identity and The Politics of Location (p. 81-92). Hampshire: Ashgate Publishing.

Sykes, M. (1908). The Kurdish Tribes of the Ottoman Empire. The Journal of the Royal Anthropological Institute of Great Britain and Ireland, 38, 458-486.

Taylor, J. G. (1865). Travels in Kurdistan, with Notices of the Sources of the Eastern and Western Tigris, and Ancient Ruins in Their Neighborhood. Journal of The Royal Geographical Society of London, (35), 21-58.

Uluç, A. (2010). Kürtler'de Sosyal ve Siyasal Örgütlenme: Aşiret. Mukaddime, (2), 35-52.

Uluç, V., Karasu, M. A. (2015). Kente Yerleşmiş Aşiret Üyelerinin Kentlileşme Eğilimleri Üzerine Bir Çalışma: Şanlıurfa Örneği. Yönetim Bilimleri Dergisi, 13 (25), 201-232.

Yalçın-Heckmann, L. (2012). Kürtlerde Aşiret ve Akrabalık IIlişkileri. G. Erkaya (Trans.). İstanbul: İletişim Yayınları.

Yamada, A. M., Marsella, A. J., \& Yamada, S. Y. (1998). The Development of the Ethno-cultural Identity Behavioral Index: Psychometric Properties and Validation with Asian Americans and Pacific Islanders. Asian American and Pacific Islander Journal of Health, 6(1), 35-45.

Zeki Beg, Muhammed E. (2015). Kürtler ve Kürdistan Tarihi. (9.Edition). V. İnce and et al (Trans.), İstanbul: Nûbihar Yayınları. 